Anna Domańska

DOI: 10.33896/PorJ.2020.3.4

(Uniwersytet Warszawski,

e-mail: a.domanska@uw.edu.pl)

\title{
POZIOM EFEKTYWNEJ BIEGLOŚCI UŻYTKOWEJ - KTO MIERZY SIE Z POZIOMEM C1 NA PAŃSTWOWYM EGZAMINIE CERTYFIKATOWYM $Z$ JĘZYKA POLSKIEGO JAKO OBCEGO?
}

W dniach 23-24 listopada 2019 r. w Centrum Języka Polskiego i Kultury Polskiej dla Cudzoziemców „Polonicum” na Wydziale Polonistyki Uniwersytetu Warszawskiego już po raz jedenasty odbył się państwowy egzamin certyfikatowy $z$ języka polskiego jako obcego. ${ }^{1}$ Tym razem 178 zdających postanowiło zdobyć formalne poświadczenie swojej znajomości polszczyzny i otrzymać państwowy certyfikat językowy wydawany przez Państwowa Komisję ds. Poświadczania Znajomości Języka Polskiego jako Obcego.

Egzamin przeprowadzono na czterech poziomach zaawansowania: B1, B2, C1 i C2. Zdający w wyborze poziomu kierują się różnymi motywacjami i nie jest to tylko - jak by się mogło wydawać - znajomość polszczyzny. Często (a nawet bardzo często) przystępowanie do egzaminu na danym poziomie jest podyktowane innymi, zwykle formalnymi wymaganiami stawianymi cudzoziemcom. Od połowy 2012 r. poziom B1 wybieraja przede wszystkim ci, którzy zamierzaja ubiegać się o polskie obywatelstwo. Zwykle sa to ludzie, którzy od wielu lat mieszkają i pracują w Polsce, polski znają na dużo wyższym poziomie, ale, ponieważ ustawodawca w procedurze towarzyszącej nadawaniu obywatelstwa wymaga urzędowego (państwowego) poświadczenia znajomości polszczyzny przynajmniej na poziomie B1, świadomie nie podejmuja ryzyka związanego $z$ wyborem wyższego poziomu. W polonistycznym środowisku glottodydaktyków i egzaminatorów określa się takich kandydatów „fałszywymi B1”. Z drugiej strony jest też znaczna grupa zdających (głów-

1 Egzaminy certyfikatowe $z$ jpjo to testy biegłości językowej, które od 2004 roku umożliwiają potwierdzenie znajomości polszczyzny (na różnych poziomach zaawansowania) oraz zdobycie państwowego certyfikatu $z$ jpjo. Więcej o egzaminach, o historii "starej” certyfikacji oraz o funkcjonowaniu systemu certyfikatowego po reformie (po 2015 r.) można przeczytać w artykule A. Domańskiej i P. Kajaka pt. Państwowe egzaminy certyfikatowe $z$ języka polskiego jako obcego na Uniwersytecie Warszawskim (po 2015 roku), „Poradnik Językowy” 2019, z. 6, s. 7-18. 
nie $z$ Ukrainy), którzy przebywają w naszym kraju niezbyt długo i, żeby zdać egzamin, powinni jeszcze jakiś czas popracować nad językiem. Ich determinacja $\mathrm{w}$ zdobyciu certyfikatu $z$ języka polskiego i zalegalizowaniu dzięki temu swojego pobytu w Polsce jest jednak tak duża, że często wybieraja jakikolwiek poziom egzaminu, byleby tylko zdać (często nie zdać, niestety) i mieć dokument. Dzieje się tak dlatego, że: po pierwsze, ludzie ci często nie maja świadomości istnienia kolejnych "stopni wtajemniczenia” znajomości języka i oznaczenia B1, B2 czy C1 niewiele im mówią (albo nic nie mówia). Po drugie, $z$ rozmów ze zdającymi wynika, że w urzędach ds. cudzoziemców uzyskują informacje o tym, że muszą zdać egzamin - bez precyzyjnego wskazania poziomu. I znowu wracamy do punktu wyjścia: jeśli cudzoziemiec nie ma rozeznania w poziomach, egzaminach itd., zapisuje się na poziom, na który aktualnie są wolne miejsca. ${ }^{2}$ Zdajacy przystępują zatem np. do poziomu B2 (listy na B1 wypełniają się najszybciej, zatem wybór pada na drugi z kolei stopień). Jak łatwo się domyślić, próby takich osób często kończą się niepowodzeniem i oznaczaja stratę pieniężną.

Poziomami najmniej „narażonymi” na „fałszywych” zdających były poziomy zaawansowane $\mathrm{C} 1 \mathrm{i} \mathrm{C} 2$. Na C2 - najwyższym z możliwych stopni zaawansowania - zdawały dotychczas (w Podmiocie Uprawnionym UW, w nowym systemie certyfikacji po 2015 r.) zaledwie 33 osoby, co stanowi ok. $1 \%$ wszystkich przystępujacych do egzaminu. ${ }^{3}$ Na podstawie tak niewielkiej liczby kandydatów trudno byłoby wysunać wiążące wnioski. Rozważania na temat testów, ich wyników czy motywacji zdających należy odsunąć w czasie. Natomiast grupa, która wydaje się ciekawa z punku widzenia wszelkich analiz, sa zdający na poziomie $\mathrm{C} 1$.

Poziom efektywnej biegłości użytkowej $\mathrm{C} 1$ wybierany był dotychczas 181 razy, co stanowi ok. 8\% wszystkich zdajacych. Do niedawna sytuacja przedstawiała się dość jasno: do egzaminu na $\mathrm{C} 1$ przystępowały osoby, które świadome (mniej lub bardziej) swoich deficytów językowych nie czuły sie jeszcze native speakerami, zatem poziom $\mathrm{C} 2$ byłby dla nich zbyt trudny. Z kolei B2, czyli poziom średniozaawansowany, stanowił już zbyt małe wyzwanie dla osób aspirujących do zdobycia kompetencji językowych na poziomie rodzimego użytkownika języka polskiego. Taki stan rzeczy utrzymywał się przez wiele sesji, aż do listopada 2019 r. Zauważono wówczas znaczny wzrost zainteresowania poziomem $\mathrm{C} 1$. Z 10-20 zdających w poprzednich sesjach liczba przystępujących do poziomu $\mathrm{C} 1$

2 Należy tu dodać, że listy na egzamin na poziomie B1 zapełniaja się w kilka minut po otwarciu rejestracji we wszystkich znanych mi ośrodkach. Liczba miejsc (na każdym poziomie) jest ograniczona $z$ powodów (głównie) logistycznych oraz formalnych (odpowiedni skład liczbowy komisji egzaminacyjnej, warunki lokalowe itd.).

3 Egzaminy na poziomie C2 przeprowadzane sa tylko raz w roku, jesienia. Dotychczas odbyły się 3 sesje. 
podczas ostatniego egzaminu wzrosła do $47 .{ }^{4}$ Niewatpliwie ma to zwiazek $z$ ostatnimi regulacjami prawnymi. Otóż zgodnie $z$ Ustawa $z$ dnia 20 lipca 2018 r-Prawo o szkolnictwie wyższym i nauce ${ }^{5}$ od cudzoziemców, którzy rozpoczęli studia w roku akademickim 2019/2020 (lub rozpoczna w następnych latach) i którzy są szczęśliwymi posiadaczami certyfikatu poświadczającego znajomość języka polskiego jako obcego na poziomie co najmniej $\mathrm{C} 1$, nie pobiera się opłat za kształcenie.

Czy nowe regulacje prawne wpłyna na frekwencję i wyniki egzaminów $\mathrm{C} 1$, na ich zdawalność, czy zmieni się profil zdających? Wydaje się, że tak. Do egzaminu prawdopodobnie będa przystępować cudzoziemcy, których główną motywacją będzie właśnie możliwość podjęcia studiów wyższych w naszym kraju. Stawka jest wysoka, więc nie możemy się dziwić, że szczęścia będa próbowały osoby dopiero aspirujące do poziomu zaawansowanego, w rzeczywistości prezentujące słabszą znajomość polszczyzny.

Poszukując potwierdzenia powyższych hipotez, postanowiliśmy poddać badaniu ankietowemu grupe przystępujacca do listopadowego (w 2019 r.) egzaminu na poziomie $\mathrm{C} 1$. Wzięło w nim udział 47 osób. Anonimową ankiete przeprowadzono przed rozpoczęciem egzaminu. W dalszej części artykułu omówione zostaną wybrane fragmenty tego postępowania.
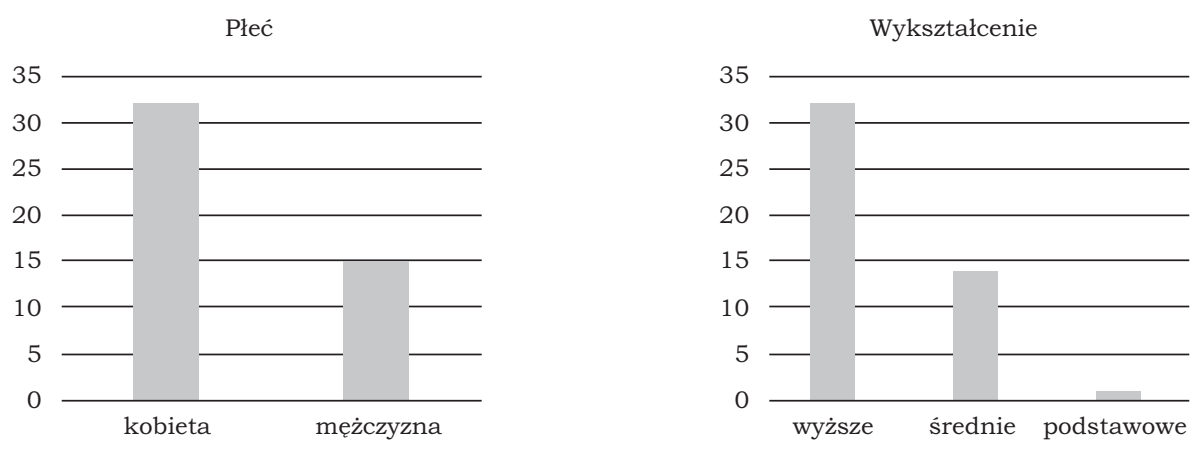

Do egzaminu przystapiły 32 kobiety (68\%) oraz 15 mężczyzn (32\%). $68 \%$ (32 osoby) deklaruje wykształcenie wyższe, 28\% wykształcenie średnie, a jedynie $2 \%$ ma wykształcenie podstawowe. Wśród osób z wyższym wykształceniem zdecydowaną większość stanowią kobiety (24), wykształcenie średnie podaje 7 kobiet i 7 mężczyzn, natomiast osoba $z$ wykształceniem podstawowym to osiemnastolatka $z$ polsko-szwedzkiej rodziny, która nie ukończyła jeszcze szkoły średniej. ${ }^{6}$

4 W momencie powstawania artykułu liczba zapisanych na C1 w sesji marcowej 2020 r. wynosiła 60 osób.

5 Dz.U. 2018, poz. 1668.

$6 \mathrm{Z}$ jednej strony, biorac pod uwage wysoki poziom egzaminu, powyższe dane dotyczace przeszłości edukacyjnej zdajacych nie stanowia zaskoczenia. $Z$ drugiej jednak strony, w odniesieniu do motywacji cudzoziemców w wyborze akurat 


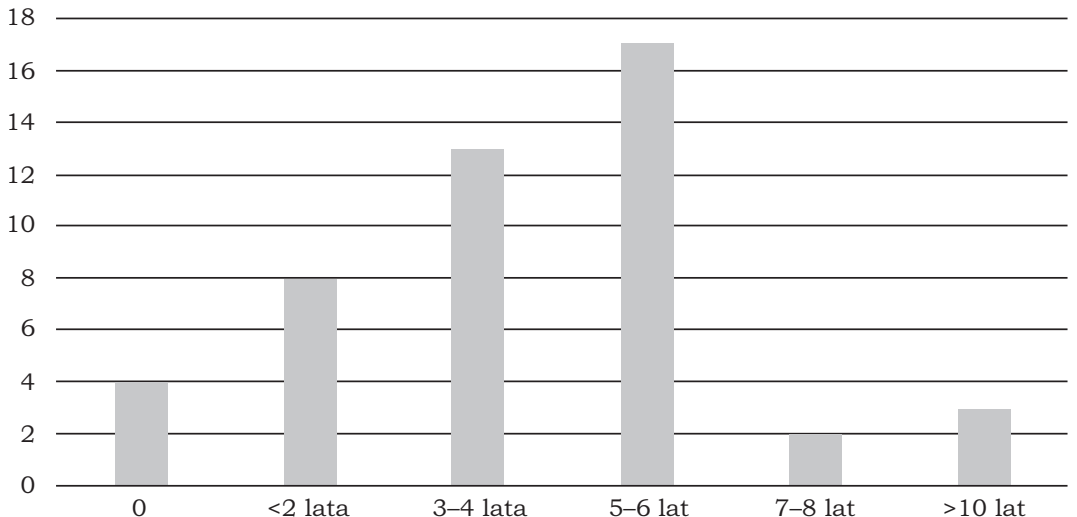

Zdecydowana większość zdających mieszka w Polsce przynajmniej od kilku lat - uśredniona długość pobytu to 4 lata i 7 miesięcy. Największą grupę stanowią ci, którzy osiedlili się w naszym kraju przed 5-6 latami i razem $z$ cudzoziemcami, którzy sa w Polsce tylko nieco krócej (3-4 lata) stanowia prawie $64 \%$ wszystkich przystępujacych do poziomu C1. 8 osób przebywa w Warszawie od ok. 2 lat, a 3 mieszkaja tu już ponad 10 lat. 4 zdajacych przyjechało na egzamin $z$ zagranicy. Państwowe egzaminy certyfikatowe odbywaja się co prawda również w ośrodkach zagranicznych, jednak ich liczba jest niewielka. ${ }^{7} \mathrm{~W}$ Czechach oraz Szwecji, skąd pochodziło dwoje kandydatów, nie ma możliwości zdania takiego egzaminu.

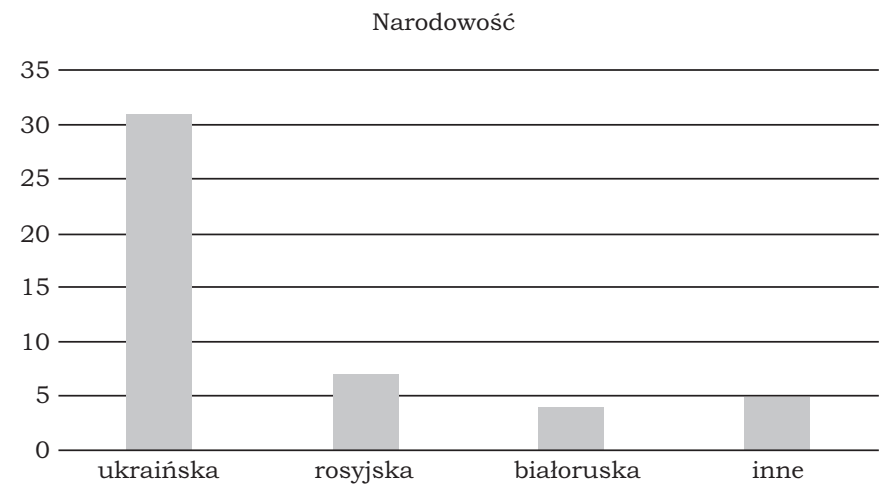

tego poziomu (studia w Polsce, będzie o tym mowa w dalszej części niniejszego artykułu), sa zastanawiajace.

7 Listę podmiotów uprawnionych do organizowania egzaminu można znaleźć na stronie: https://www.gov.pl/web/nauka/lista-podmiotow-uprawnionychdo-organizowania-egzaminow-z-jezyka-polskiego-jako-obcego 
Najliczniej reprezentowanym krajem pochodzenia zdajacych jest Ukraina (narodowość ukraińska dominuje nie tylko na poziomie C1). Podczas omawianego egzaminu obywatele $z$ tego kraju stanowili niemal $66 \%$ wszystkich zdających (31 osób). Drugim, co do liczby reprezentantów, krajem była Rosja, której 7 obywateli stanowiło 15\% zdających, następnym Białoruś z 4 przedstawicielami (prawie 9\%), a w dalszej kolejności, reprezentowane przez jednego zdającego każda, uplasowały się narodowości: czeska, japońska, kazachska i polska, a jeden ankietowany zadeklarował narodowość polsko-szwedzka. Wyraźna przewaga obywateli Ukrainy utrzymuje się niezmiennie od kilku lat, a lawinowy wzrost zainteresowania certyfikatem odnotowano po wprowadzeniu regulacji dotyczących obywatelstwa (sierpień 2012 r.).

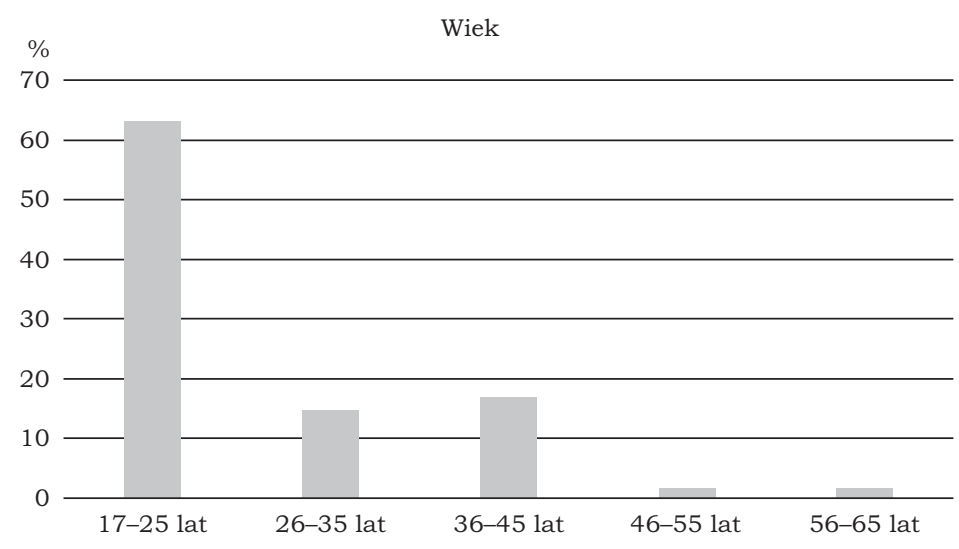

Najmłodszy zdający miał 17 lat $^{8}$ i wraz $z$ pozostałymi osobami $\mathrm{w}$ wieku do 25 lat reprezentował najliczniejszą kategorię wiekową. Ludzie młodzi (17-25 lat) stanowia bowiem ponad 60\% wszystkich zdajacych (29 osób), kolejna grupa sa zdający w wieku 26-35 lat (7 osób) oraz 36-45 lat (8 osób). Do egzaminu przystapiły tylko dwie osoby powyżej 45 lat, co stanowi 4\% zdajacych. Najstarszy egzaminowany miał 65 lat, jedna osoba nie ujawniła swojego wieku.

Prezentowany rozkład wieku odbiega nieco od ogółu populacji zdających, zwłaszcza na poziomie B1. Przypomnijmy, że wybieraja go głównie ludzie ubiegający się o polskie obywatelstwo, mieszkajaccy w Polsce wiele lat, często prowadzacy tu własne firmy, a zatem ludzie raczej z przedziału 36-55 lat i starsi. ${ }^{9}$ Poziom C1 rządzi się jednak innymi prawami i fakt,

8 W szczególnych wypadkach, za zgodą Podmiotu Uprawnionego, możliwe jest zdawanie egzaminu dla dorosłych przez osobę niepełnoletnią.

9 Potwierdzenie obserwowanych - w trakcie kilkunastu już sesji egzaminacyjnych - tendencji, dotyczacych wyboru poziomów, wieku zdajacych, ich pochodzenia itp., uzyskaliśmy w trakcie opracowywania szczegółowych danych 
że wybieraja go przede wszystkim młodzi, nie dziwi, jeśli spojrzymy na niego szerzej i wiek powiążemy z motywacjami zdających. Najliczniejsza grupa sa bowiem cudzoziemcy, którzy albo nie podjęli jeszcze studiów w swoich krajach i Polska jest dla nich miejscem, gdzie chcieliby zdobyć wyższe wykształcenie, albo ludzie, którzy przyjechali tu już po studiach pierwszego stopnia (często też drugiego, por. wykres prezentujacy wykształcenie) i chcieliby kontynuować edukację wyższą w naszym kraju. A, jak już wspomniano wcześniej, najkorzystniejsze dla obcokrajowca jest zdobycie dyplomu dobrej polskiej uczelni na prawach równych prawom polskiego obywatela.

Przyjrzyjmy się zatem, co wpłynęło na decyzję ankietowanych o przystapieniu do egzaminu państwowego.

Motywacje zdajacych na poziomie $\mathrm{C} 1$

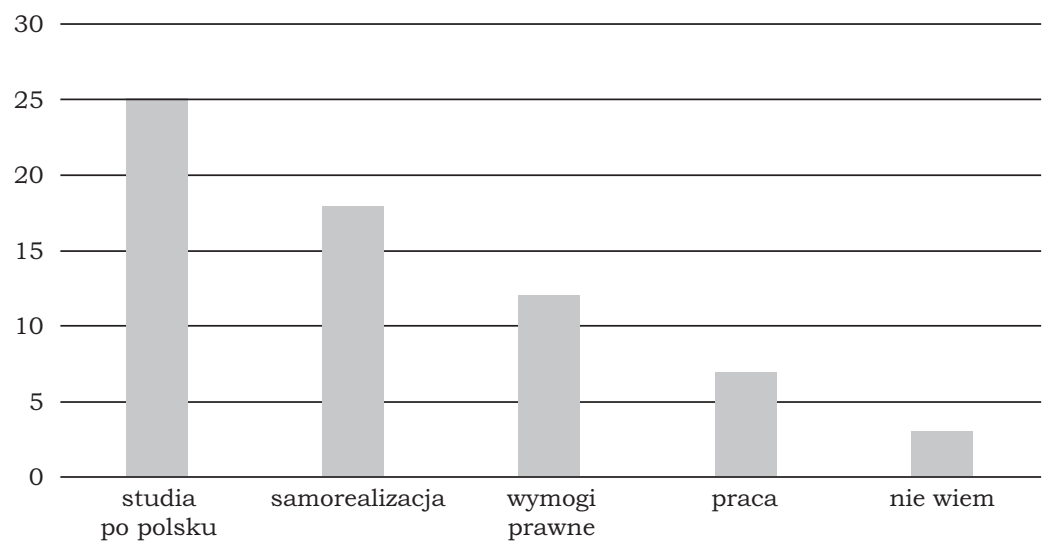

Jak widać, zdecydowana większość zdających wskazała studia po polsku jako główny powód ubiegania się o certyfikat na poziomie C1 (ankietowani mogli wybrać więcej niż jedną opcję). 24 osoby spośród $25 \mathrm{w}$ wieku od 17 do 23 lat przystapiły do egzaminu po to, aby móc ubiegać się o miejsce na polskiej uczelni. Badani wprost pisali (w uwagach), że interesuje ich „bezpłatne studiowanie na uniwersytecie”, że zdają: „żeby mieć możliwość studiować bez opłat”, „żeby zwolnili mnie $z$ opłaty na uniwersytecie”, „bo chcę kontynuować studia wyższe za darmo”. Często wybierana kategoria (18 razy, prawie zawsze jako element dodatkowy) była potrzeba samorealizacji, a w dalszej kolejności wymogi prawne (12 osób). W tym kontekście trzeba odwołać się do słów Władysława Miodunki, który określił egzaminy certyfikatowe mianem doniosłych. Krakowski badacz uznał bowiem, że w wypadku polskiego systemu egzaminy zyskały

dotyczacych populacji zdajacych w Podmiocie Uprawnionym UW. Wyniki tych badań zostaną opublikowane w najbliższych miesiącach. 
na znaczeniu i „doniosłości”, kiedy to w 2012 roku Ustawa o obywatelstwie polskim nałożono na cudzoziemców (ubiegających się o polskie obywatelstwo) obowiazek posiadania certyfikatu $z$ jpjo przynajmniej na poziomie B1. Czy nowe regulacje prawne zwalniające cudzoziemca $z$ opłat za studiowanie w języku polskim „podnosza”, potwierdzaja doniosłość systemu certyfikacji? Wyniki przeprowadzonej ankiety oraz gwałtowny wzrost zainteresowania poziomem $\mathrm{C} 1$ daja jednoznaczne świadectwo, iż tak właśnie jest. Certyfikat $z$ języka polskiego jest wysoko pożądanym produktem, należy do najważniejszych innowacji pedagogicznych w glottodydaktyce polonistycznej, doskonale promuje polszczyznę w świecie - o czym nikogo nie trzeba już przekonywać.

Kolejne pytanie ankietowe sprawdzało świadomość zdajacych związana ze stanem własnego przygotowania do egzaminu. Ankietowanych poproszono o odpowiedź na pytanie, czy ich przygotowanie było wystarczające, niewystarczające, czy też trudne do określenia. Okazało się, że tylko 4 osoby oceniły stan swoich przygotowań negatywnie. Pozostali zdający podzieli się na dwie niemal równe części: $22 \mathrm{z}$ nich okazało się optymistami (realistami?), uznajac, że sa wystarczajaco dobrze przygotowani do czekającego ich wyzwania, natomiast 20 osób udzieliło odpowiedzi: „nie wiem”. Jednocześnie 43 badanych, a więc ponad $90 \%$ kandydatów, przyznało, że miało dostęp do testów przykładowych, a 40 zdających (ponad $85 \%$ ) z nich skorzystało. Skąd zatem wzięła się tak duża grupa niepewnych swojego losu? Tu można tylko domniemywać, zostawiając na boku czynniki psychologiczne, że część z nich to zapewne „ryzykanci”, którym test przykładowy nie dał jednoznacznej odpowiedzi, czy sa już gotowi na trudny poziom efektywnej biegłości użytkowej (C1), czy jeszcze nie. Nawet przy nie najlepszym wyniku pretestu kandydaci postanowili walczyć o potrzebny im certyfikat (por. fragment niniejszego artykułu, poświęcony motywacjom).

Zaskakuje korelacja między świadomością własnych kompetencji w poszczególnych sprawnościach językowych a realnymi umiejętnościami zdajacych w tym zakresie. Poproszono ankietowanych o wskazanie na skali najsłabszej oraz najmocniejszej kompetencji (rozumienie ze słuchu - RS, rozumienie tekstów czytanych - RT, poprawność gramatyczna - PG, pisanie - P i mówienie - M). Okazuje się, że najwyżej oceniana w autoewaluacji sprawnościa jest RT, dalej M, potem RS, następnie PG, a najtrudniejsze w oczach zdajacych jest pisanie (przy czym pisania i gramatyki obawiano się niemal w równym stopniu).Wyniki egzaminu pokazały, że zdający perfekcyjnie potrafili wskazać swoje mocne strony: sprawnościa, w której uzyskano najlepsze wyniki, było właśnie RT (średnia uzyskana przez wszystkich zdajacych - 84\%), dalej znalazło się M $(78 \%)$ oraz RS (74\%) i P (70\%). Częścią, która wypadła znacząco gorzej, niż zakładali zdający, jest poprawność gramatyczna. Jakie są tego przyczyny? Czy zbyt dużym wyzwaniem okazały się same zagadnienia gramatyczne, których wymaga się od zdajacych na poziomie C1? Czy 
może wpływ na taki stan rzeczy miały techniki testowania wykorzystane w tej części egzaminu? Testy zdających poddane zostana (późniejszej) szczegółowej analizie, co $z$ pewnościa pozwoli na bardziej precyzyjne odpowiedzi na powyższe pytania. Jednakże już dziś można przypuszczać, że rozdźwięk między stanem świadomości gramatycznej a rzeczywistymi rezultatami egzaminów $z$ tej sprawności wynika raczej $z$ błędnego przekonania samych zdających na temat własnych kompetencji w tym zakresie. Zjawisko to ma dość oczywiste podłoże: jeśli rozumiem wszystko (albo prawie wszystko) w języku obcym (kiedy czytam i kiedy słucham), porozumiewam się bez problemu, nie tylko w sprawach codziennych, ale również w pracy, na uczelni, w urzędzie, to mam prawo sądzić, że moja wiedza gramatyczna również nie jest najgorsza. Gramatyka języka polskiego, zdaniem zdajacych, stereotypowo nie należy do najłatwiejszych. Jednakże cudzoziemiec mierzacy się $z$ egzaminem państwowym otrzymuje dostęp do wielu narzędzi (standardów wymagań egzaminacyjnych, katalogu koniecznych do opracowania zagadnień gramatycznych, testów przykładowych, publikacji dydaktycznych przeznaczonych dla danego poziomu), uniemożliwiajacych jakiekolwiek zaskoczenie. Niestety, aż dla 14 osób, czyli prawie $30 \%$ zdających, egzamin zakończył się niepowodzeniem. Każda $z$ tych osób nie zdała gramatyki, ale tylko dla dwóch $z$ nich była to jedyna niezdana sprawność. Najczęściej gramatyce towarzyszyło pisanie (co jest zrozumiałe, albowiem nie da się sformułować dobrego tekstu bez znajomości reguł gramatycznych), rzadziej słuchanie oraz mówienie. 6 osób nie poradziło sobie $z$ więcej niż trzema sprawnościami. Warto dodać, że średnia, jaka osiagnęli wszyscy zdający ze sprawności poprawność gramatyczna, wyniosła zaledwie $64 \%$, a więc niewiele więcej niż wymagany do zaliczenia próg $60 \%$. Wyniki jasno pokazuja, że tym razem do egzaminu przystapili przede wszystkim cudzoziemcy dopiero aspirujacy do poziomu $\mathrm{C} 1$, którzy powinni poświęcić jeszcze wiele uwagi nie tylko polskiej gramatyce, ale i innym zagadnieniom dotyczacym poprawnej polszczyzny.

\begin{tabular}{|c|c|c|}
\hline sprawności & samoocena & wyniki egzaminu \\
\hline $\mathrm{RT}$ & $81 \%$ & $84 \%$ \\
\hline $\mathrm{M}$ & $79 \%$ & $78 \%$ \\
\hline $\mathrm{RS}$ & $74 \%$ & $74 \%$ \\
\hline $\mathrm{PG}$ & $70 \%$ & $64 \%$ \\
\hline $\mathrm{P}$ & $69 \%$ & $70 \%$ \\
\hline
\end{tabular}

Tabela przedstawia korelację samooceny zdających z wynikami egzaminu.

Odpowiadając na pytanie postawione w tytule niniejszego artykułu, należy stwierdzić, iż „statystyczny” zdający, który zmierzył się z poziomem efektywnej biegłości użytkowej C1 (w listopadzie 2019 r. w PU UW) to młoda, wykształcona kobieta $z$ Ukrainy, mieszkająca w Polsce od 4 lat 
i 7 miesięcy. Głównym powodem jej starania się o certyfikat jest możliwość bezpłatnego studiowania na polskiej uczelni - mimo że wykształcenie wyższe (I lub II stopnia) zdobyła już we własnym kraju. ${ }^{10} \mathrm{~W}$ kolejnych sesjach egzaminacyjnych nie należy spodziewać się radykalnych zmian, utrzymaja się raczej podobne tendencje zarówno dotyczace profilu zdajacych, jak i wyników egzaminu $\mathrm{C} 1$.

\section{Bibliografia}

A. Domańska, P. Kajak, Państwowe egzaminy certyfikatowe $z$ języka polskiego jako obcego na Uniwersytecie Warszawskim (po 2015 roku), „Poradnik Językowy" 2019, z. 6, s. 7-18.

A. Pawłowski, 2015, Promocja języka polskiego - między lingwistyka a marketingiem, „Poradnik Językowy” 2015, z. 8, s. 143-155.

W.T. Miodunka, Wartość języka polskiego na międzynarodowym rynku edukacyjnym i na rynku pracy [w:] E. Lipińska, A. Seretny (red.), $Z$ zagadnień $d y-$ daktyk języka polskiego jako obcego, Kraków 2006, s. 323-331.

G. Zarzycka, Wpływ egzaminów certyfikatowych z języka polskiego jako obcego na status polszczyzny $w$ świecie oraz na zmiany $w$ glottodydaktyce polonistycznej, „Rozprawy Komisji Językowej ŁTN” 2016, t. LXII, s. 223-227.

\section{Effective operational proficiency or who takes the level C1 certification examination in Polish as a foreign language?}

\section{Summary}

The $11^{\text {th }}$ examination session for foreigners taking the state examination in Polish as a foreign language at four levels (B1-C1) was held at the University of Warsaw in autumn 2019. The group taking the examination at the level of effective operational proficiency (C1) were subject to a survey. The paper describes its selected aspects, such as age, gender, education, nationality, and motivations of the examinees. The results of the examined foreigners' selfassessment were compared to the results they achieved in individual language skills. The motives for taking the examination were discussed extensively and particular attention was drawn to the new legal reality, which played (and will probably play) a major role in selecting the $\mathrm{C} 1$ level.

Keywords: Polish as a foreign language - certification - level C1 - certification examination in Polish as a foreign language.

Trans. Monika Czarnecka

10 Prawdopodobnie jest to jeden ze sposobów na usankcjonowanie pobytu w kraju Unii Europejskiej. 